\title{
Reinstatement of Paragrandidierella (Crustacea: Amphipoda: Aoridae) from Japan, with the Description of a New Species
}

\author{
Hiroyuki Ariyama \\ Marine Fisheries Research Center, Research Institute of Environment, Agriculture and Fisheries, \\ Osaka Prefecture, Tanagawa, Misaki, Osaka 599-0311 Japan \\ E-mail: AriyamaH@mbox.kannousuiken-osaka.or.jp
}

(Received 28 May 2013; Accepted 9 October 2013)

\begin{abstract}
Paragrandidierella (Crustacea: Amphipoda: Aoridae) is reinstated for three species from Japan, P. minima Ariyama, 2002, P. unidentata (Ren, 2006), and P. urauchiensis sp. nov. Eight morphological features distinguish these species from species of the genus Grandidierella, with which Paragrandidierella was synonymized. Paragrandidierella urauchiensis sp. nov. was collected from a tidal flat at the mouth of the Urauchi River, Iriomote Island, Okinawa Prefecture. This new species has long antennae and a long, acute tooth on the posterodistal corner of the gnathopod 1 carpus in males. Paragrandidierella unidentata was collected from a tidal flat at the mouth of the Waka River, Wakayama Prefecture, as the first record of this species in Japan. It is characterized by a short antenna 2 and a short tooth on the posterodistal corner of the gnathopod 1 carpus in males. The morphology of the antennae, the detailed structure of the mouthparts, and the change in shape with growth of P. minima, the type species of the genus, are also described. A key to the species of the genus is provided.
\end{abstract}

Key Words: non-synonymous genus, Paragrandidierella, new species, Aoridae, Amphipoda, Crustacea, Japan, key.

\section{Introduction}

The amphipod genus Paragrandidierella was established by Ariyama (2002) with P. minima Ariyama, 2002 as its type species, characterized by a carpochelate male gnathopod 1 , reduced uropods, a uniramous uropod 3, and a short telson with a pair of dorsal swellings. Afterwards, Ren (2006) recorded P. minima from China, but synonymized this genus with Grandidierella Coutière, 1904 for the reason that they are difficult to distinguish morphologically. Recently, Jung and Yoon (2013) recorded P. minima also from Korea and they stated that Paragrandidierella is surely separated from Grandidierella because of some distinct differences.

During a survey of the amphipod fauna in Japan, three species referable to Paragrandidierella were obtained. Close examination has revealed that they possess in common several morphological features that species of Grandidierella species do not share. Based on the features, Paragrandidierella is removed from the synonym of Grandidierella and reinstated as a valid genus. One of the three species is undescribed species and one is new to Japan; both are described here in detail. As for P. minima, the morphology of antenna 1 , the detail structure of the mouthparts, and the change in shape with growth, which were not described by Ariyama (2002), are described herein. In addition, a key to the species is provided. Body length was measured from the apex of the rostrum along the dorsal margin to the distal end of the telson. The material examined is deposited in the Osaka Museum of Natural History (OMNH), Osaka, Japan.
Paragrandidierella Ariyama, 2002

[Japanese name: Himedorosokoebi-zoku]

Paragrandidierella Ariyama, 2002: 155.

Grandidierella: Ren 2006: 368 (in part).

Emended diagnosis. Body subcylindrical, somewhat compressed dorsoventrally, smooth. Rostrum indistinct. All pereon segments lacking ventral process. Urosomites free, short. Antenna 1 slender, peduncular article 3 much shorter than article 1, accessory flagellum vestigial; antenna 2 peduncle rather stout. Upper lip entire. Mandibular palp slender, articles 2 and 3 longer than article 1, article 3 rectolinear; incisor small, with 3-4 cusps, lacinia mobilis with 2-3 cusps, accessory blades 4 in left mandible, 5 in right. Lower lip with long mandibular process; apical margin of inner lobe with minute projection. Inner plate of maxilla 1 indistinct; outer plate pointed apically, with 3 stout robust setae and 5-7 normal setae distally; palp 2-articulate, slender, curved medially, with 3 short setae at tip. Inner plate of maxilla 2 elongate-triangular, margin with row of setae; apical margin of outer plate truncate, bearing many setae. Inner plate of maxilliped lacking distal robust setae; outer plate broad, exceeding apex of palp article 2, with 6 marginal robust setae; palp consisting of 4 articles, article 3 bearing robust seta dorsodistally, article 4 with claw. Coxae small, almost disjunct, coxa 5 widest; coxal gills present on pereopods 2-6; oostegites of female narrow, present on pereopods 2-5. Male gnathopod 1 enlarged, carpochelate; basis wide, ischium short, merus triangular, carpus broad, with tooth on posterodistal corner, propodus smaller than carpus. Fe- 
male gnathopod 1 smaller than that of male, simple; carpus longer than propodus, propodus with 3-4 robust setae on posterior margin. Gnathopod 2 of both sexes smaller than gnathopod 1, simple; carpus longer than propodus, propodus with 2 robust setae each on posterodistal corner and posterior margin, dactylus short. Pereopods 3 and 4 similar to each other, slender; bases and propodi elongate, dactyli narrow. Pereopods 5-7 progressively increasing in length, pereopod 7 more than twice as long as pereopod 5; posteroproximal corner of basis of pereopods 5 and 6 produced, posterior margin of both coxae bearing plumose setae. Epimeral plates rounded posteroventrally. Pleopods short, peduncles each with a few plumose setae and 2 coupling hooks, outer ramus shorter than inner. Uropods reduced; uropod 1 biramous, stout, peduncle shorter than rami, with long inter-ramal process, both rami with several dorsal and distal robust setae; uropod 2 biramous, about half as long as uropod 1, inter-ramal process absent, tips of outer and inner rami with 2 and 4 robust setae, respectively; uropod 3 uniramous, about half as long as uropod 2, with several long setae terminally. Telson extremely short, entire, with pair of dorsal swellings.

Type species. Paragrandidierella minima Ariyama, 2002 (by monotypy).

Remarks. Although synonymized with Grandidierella by Ren (2006), Paragrandidierella is clearly different from Grandidierella in the following respects (features of Grandidierella in parentheses): (1) lower lip with minute projection on apical margin of inner lobe (no projection); (2) outer plate of maxilla 1 pointed apically, with 3 stout robust setae and 5-7 normal setae distally (not pointed, $c a .10$ ordinary robust setae); (3) palp of maxilla 1 slender, with 3 short setae at tip (wide, with several robust setae at tip); (4) outer plate of maxilliped exceeding apex of palp article 2 (not reaching so far distally); (5) female gnathopod 1 simple (subchelate); (6) gnathopod 2 of both sexes simple (subchelate); (7) peduncle of uropod 1 stout, with long inter-ramal process (slender, with short inter-ramal process); and (8) telson extremely short with pair of dorsal swellings (relatively long, without swellings). These differences confirm the validness of Paragrandidierella. Ariyama (2002) described gnathopod 2 of both sexes of $P$. minima as "subchelate"; however, I correct this to "simple" based on the range of specimens studied herein.

The features of Paragrandidierella for separating from Grandidierella by Jung and Yoon (2013) almost share with those of Ariyama (2002) and the above features. However, two features are different: absence of accessory flagellum on antenna 1 and posterodistal protrusion on peduncle 5 of antenna 2. In the former, there is a possibility of overlooking because of its minuteness, and the latter is not a generic feature as stated below.

Included taxa. Paragrandidierella minima; P. unidentata; $P$. urauchiensis sp. nov.
Paragrandidierella urauchiensis sp. nov.

(Figs 1-4)

[New Japanese name: Urauchi-himedorosokoebi]

Paragrandidierella sp.: Association of Interdisciplinary Study at the Drainage and Estuarine Area of Urauchi River, Iriomote Island, Southern Japan 2006: 18, fig. 7c-1.

Material examined. Holotype: male (OMNH-Ar9543), $3.1 \mathrm{~mm}$, mouth of Urauchi River in Iriomote Island, Okinawa Prefecture $\left(24^{\circ} 24.9^{\prime} \mathrm{N}, 123^{\circ} 46.7^{\prime} \mathrm{E}\right)$, tidal flat near stand of mangroves Rhizophora stylosa Griffith, 3 September 2005, coll. N. Okuda et al. Paratypes: one male (OMNHAr-9544), $3.2 \mathrm{~mm}$, same data as holotype; two males (OMNH-Ar-9545, 9546), 3.0, $2.6 \mathrm{~mm}$, one ovigerous female (OMNH-Ar-9547), $2.5 \mathrm{~mm}$, and one female (OMNHAr-9548), $2.4 \mathrm{~mm}$, same place, 7 March 2005, coll. N. Okuda et al.

Description of male [based mostly on holotype, supplemented by one paratype (OMNH-Ar-9545) for lower lip, telson, and uropod 3]. Body (Fig. 1) slender. Eyes medium-sized (18\% as long as head). Posteroventral corners of pereonites 5-7 strongly produced. Urosomites without dorsal keel or ridge.

Antenna 1 (Fig. 2A, A1) long, about 0.7 times as long as body; length ratio of peduncular articles 1-3 1.0:1.0:0.3; flagellum with 16 normal and 1 minute articles, articles 7-16 each with aesthetasc on ventrodistal corner. Antenna 2 (Fig. 2B) relatively short, length (peduncular articles 3-5 and flagellum) about half as long as body; length ratio of peduncular articles 3-5 1.0:1.3:1.0, ventrodistal corner of article 5 not inflated; flagellum short, but longer than peduncular article 5, consisting of 7 normal and 1 minute articles, flagellar articles 3-7 each with 2 robust setae.

Upper lip (Fig. 2C) with ventral margin almost straight, bearing many thin setae. Left mandible (Fig. 2D, D1) with length ratio of palp articles 1-3 1.0:2.5:1.7, articles 2 and 3 with 2 and 8 setae, respectively; incisor with 3 cusps, lacinia mobilis with 2 cusps. Right mandible (Fig. 2E, E1) with length ratio of palp articles $1-3 \quad 1.0: 2.5: 2.0$, articles 2 and 3 with 2 and 7 setae, respectively; incisor with 4 cusps, lacinia mobilis with 3 cusps. Lower lip (Fig. 2F) covered with thin setae on apical parts of outer and inner lobes. Maxilla 1 (Fig. $2 \mathrm{G}, \mathrm{G} 1, \mathrm{G} 2$ ) with outer plate bearing 3 robust and 7 normal setae. Maxilla 2 (Fig. $2 \mathrm{H}$ ) with inner plate setose on distal margin, inner margin with sparse fine setae. Maxilliped (Fig. 2I, I1) with inner plate produced mediodistally, distal and medial margins bearing many plumose setae; outer plate broad, middle and proximal parts strongly inflated laterally, medial margin with 2 plumose setae and 6 thick, robust setae.

Gnathopod 1 (Fig. 3A, A1) greatly enlarged; carpus extremely wide, posterodistal corner with long, acute tooth (ca. $55 \%$ as long as carpus proper); propodus narrow, middle part of posterior margin expanded; dactylus elongatetriangular, distal part of posterior margin with 2 minute notches. Gnathopod 2 (Fig. 3B, B1) slender; posterodistal margin of merus setose; carpus elongate, posterior margin 


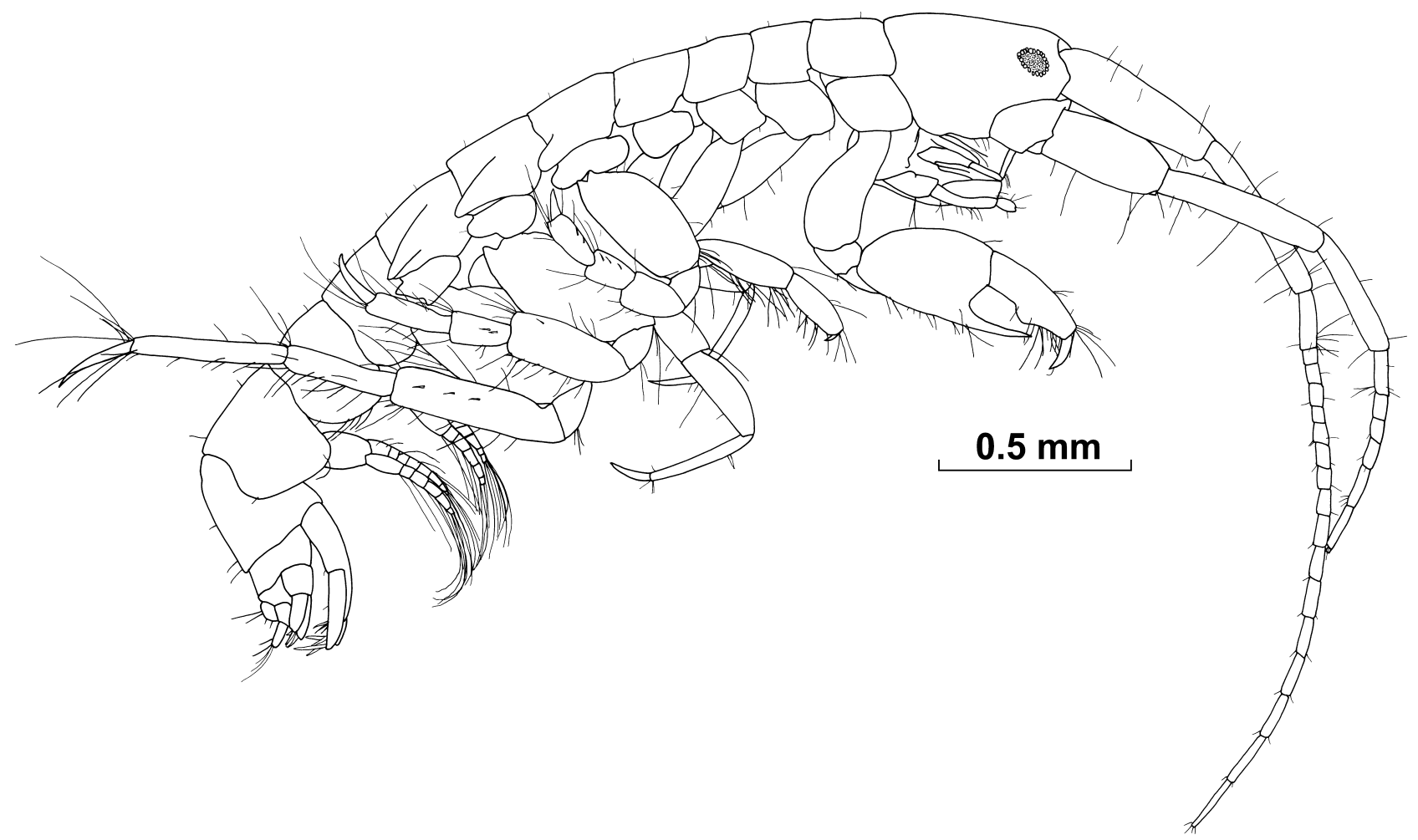

Fig. 1. Paragrandidierella urauchiensis sp. nov. Holotype male (OMNH-Ar-9543), $3.1 \mathrm{~mm}$. Habitus, right lateral view.

with many thick and normal setae; propodus relatively long; dactylus with 3 denticles posterolaterally.

Pereopods 3 and 4 (Fig. 3C, C1, D) with coxae roundishrectangular, bases slender, meri dilated distally, carpi longer than meri, propodi narrow, and dactyli long and dirkshaped. Pereopod 5 (Fig. 3E) with coxa short, posterior half narrower than anterior; basis rectangular, anterodistal corner with several setae; merus relatively broad; carpus with 3 lateral and 1 posterodistal robust setae; propodus with 3 lateral and 2 posterodistal robust setae; dactylus short, with plumose seta. Pereopod 6 (Fig. 3F) about 1.4 times as long as pereopod 5; coxa with posterior half narrower than anterior; basis relatively broad, anterior margin with 2 short robust setae, distal half of posterior margin with many plumose setae and 3 robust setae; merus with 3 anterior and 1 lateral robust setae; carpus with 4 lateral robust setae, anterodistal and posterodistal corners bearing thick setae; propodus with 4 lateral robust setae, posterior margin and anterodistal corner with long setae; dactylus bearing plumose seta. Pereopod 7 (Fig. 3G) about 1.5 times as long as pereopod 6; coxa small, anterior part produced ventrally; basis ovoidal, anterior margin with short robust seta, anterodistal part of lateral surface bearing several plumose setae, posterior margin with many plumose setae and 3 robust setae; merus with 1 lateral and 4 medial robust setae; carpus with 6 lateral and 1 medial robust setae; propodus bearing 4 robust setae on anterior margin and 2 medial thick setae, anterodistal corner with long, thick seta; dactylus with plumose seta.

Epimeral plates 1-3 (Fig. 4A) each with 1-4 long, plumose setae on ventral margin and short seta on posteroven- tral corner. Pleopods (Fig. 4B-D) with outer rami of 7-8 articles, inner rami of 6 articles. Uropod 1 (Fig. 4E) stout; dorsal surface of peduncle with 2 robust setae distally; outer ramus slightly longer than inner, former with 2 dorsal and 4 terminal robust setae, latter bearing 1 dorsal and 4 terminal robust setae. Uropod 2 (Fig. 4F) with peduncle shorter than wide; rami a little longer than peduncle, outer ramus shorter than inner. Uropod 3 (Fig. 4G) with peduncle a little shorter than single ramus, latter with 4-5 long setae terminally. Telson (Fig. 4G) with several setae on margins and swellings.

Description of female [based on paratype (OMNHAr-9548)]. Generally similar to male holotype except for antennae, gnathopods, and oostegites. Antenna 1 (Fig. 4H) relatively short, about 0.45 times as long as body; length ratio of peduncular articles 1-3 1.0:0.9:0.4; flagellum with 9 normal and 1 minute articles, articles 6, 8, and 9 each with aesthetasc on ventrodistal corner. Antenna 2 (Fig. 4I) short, 0.3 times as long as body; length ratio of peduncular articles 3-5 1.0:1.3:1.4; flagellum very short, same length as peduncular article 5, consisting of 3 normal and 1 minute articles, flagellar articles 2 and 3 each with 2 robust setae. Gnathopod 1 (Fig. 4J, J1) with coxa trapezoidal; basis broadened distally; merus triangular, posterior margin with a few setae; carpus relatively broad, posterior margin with several thick and normal setae; propodus slender, distal half of posterior margin with 3 robust setae; dactylus with denticle on distal part of posterior margin. Gnathopod 2 (Fig. 4K, K1) subequal in size to gnathopod 1 , similar to that of male, but carpus and propodus shorter.

Variation in male gnathopod 1 (4 males examined). Small male [paratype, $2.6 \mathrm{~mm}$ (OMNH-Ar-9546), 


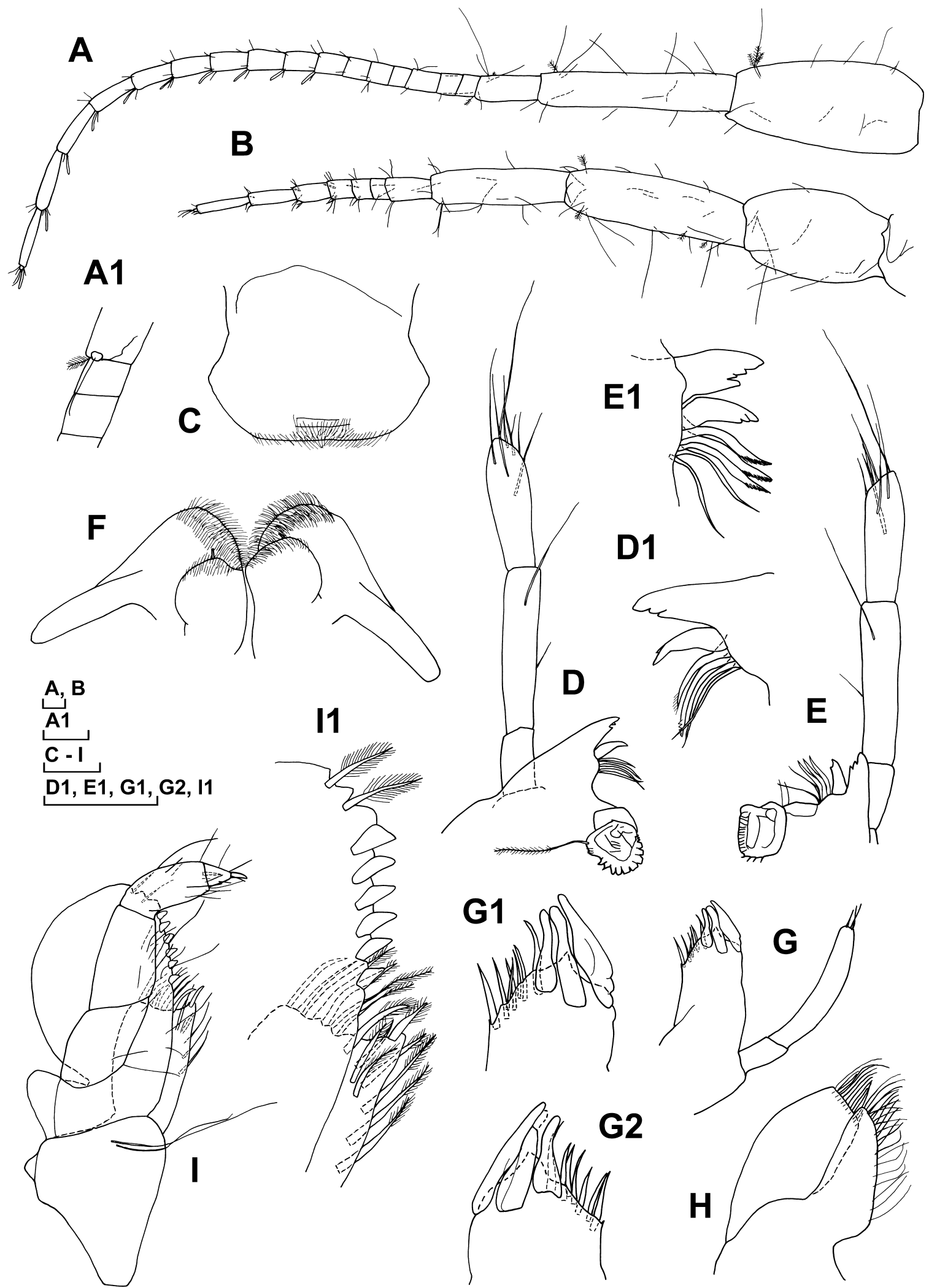

Fig. 2. Paragrandidierella urauchiensis sp. nov. A-E, G-I, holotype male (OMNH-Ar-9543), $3.1 \mathrm{~mm}$; F, paratype male (OMNH-Ar-9545), $3.0 \mathrm{~mm}$. A, left antenna 1, lateral view; A1, accessory flagellum and adjacent part of left antenna 1, medial view; B, left antenna 2, lateral view; C, upper lip, anterior view; D, left mandible, medial view; D1, incisor, lacinia mobilis, and accessory blades of left mandible, lateral view; E, right mandible, medial view; E1, incisor, lacinia mobilis, and accessory blades of right mandible, medial view; F, lower lip, ventral view; G, right maxilla 1, dorsal view; G1, distal part of outer plate of right maxilla 1, dorsal view; G2, distal part of outer plate of left maxilla 1, dorsal view; $H$, right maxilla 2, ventral view; I, right maxilliped, ventral view; I1, outer and inner plates of right maxilliped, ventral view, normal setae omitted. Scales: $0.05 \mathrm{~mm}$. 


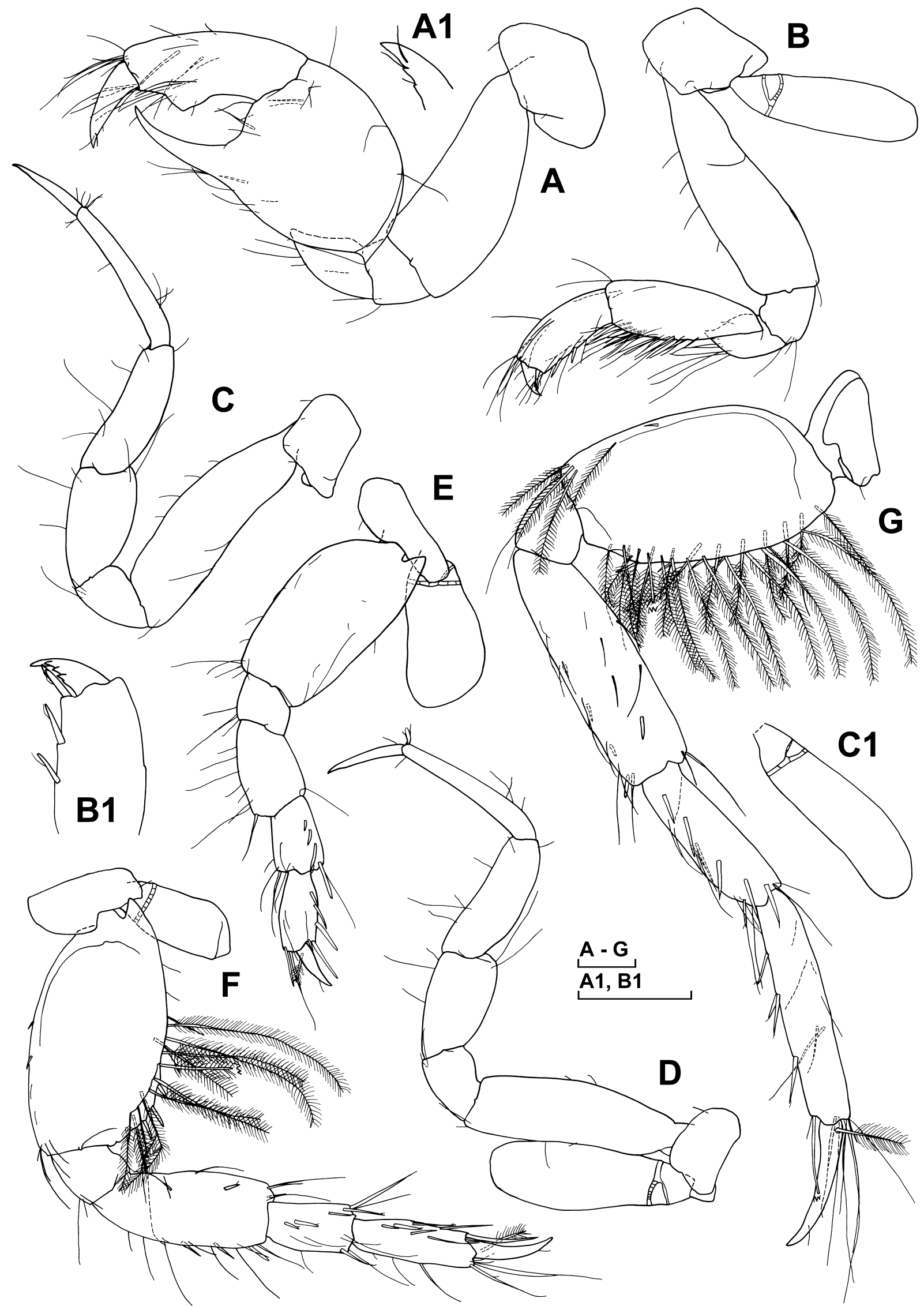

Fig. 3. Paragrandidierella urauchiensis sp. nov. Holotype male (OMNH-Ar-9543), $3.1 \mathrm{~mm}$. A, left gnathopod 1, lateral view; A1, tip of dactylus of left gnathopod 1, lateral view; B, left gnathopod 2, lateral view; B1, propodus and dactylus of left gnathopod 2, lateral view, normal setae omitted; C, left pereopod 3, lateral view; C1, coxal gill of left pereopod 3, lateral view; D-G, left pereopods 4-7, lateral views. Scales: $0.1 \mathrm{~mm}$. 

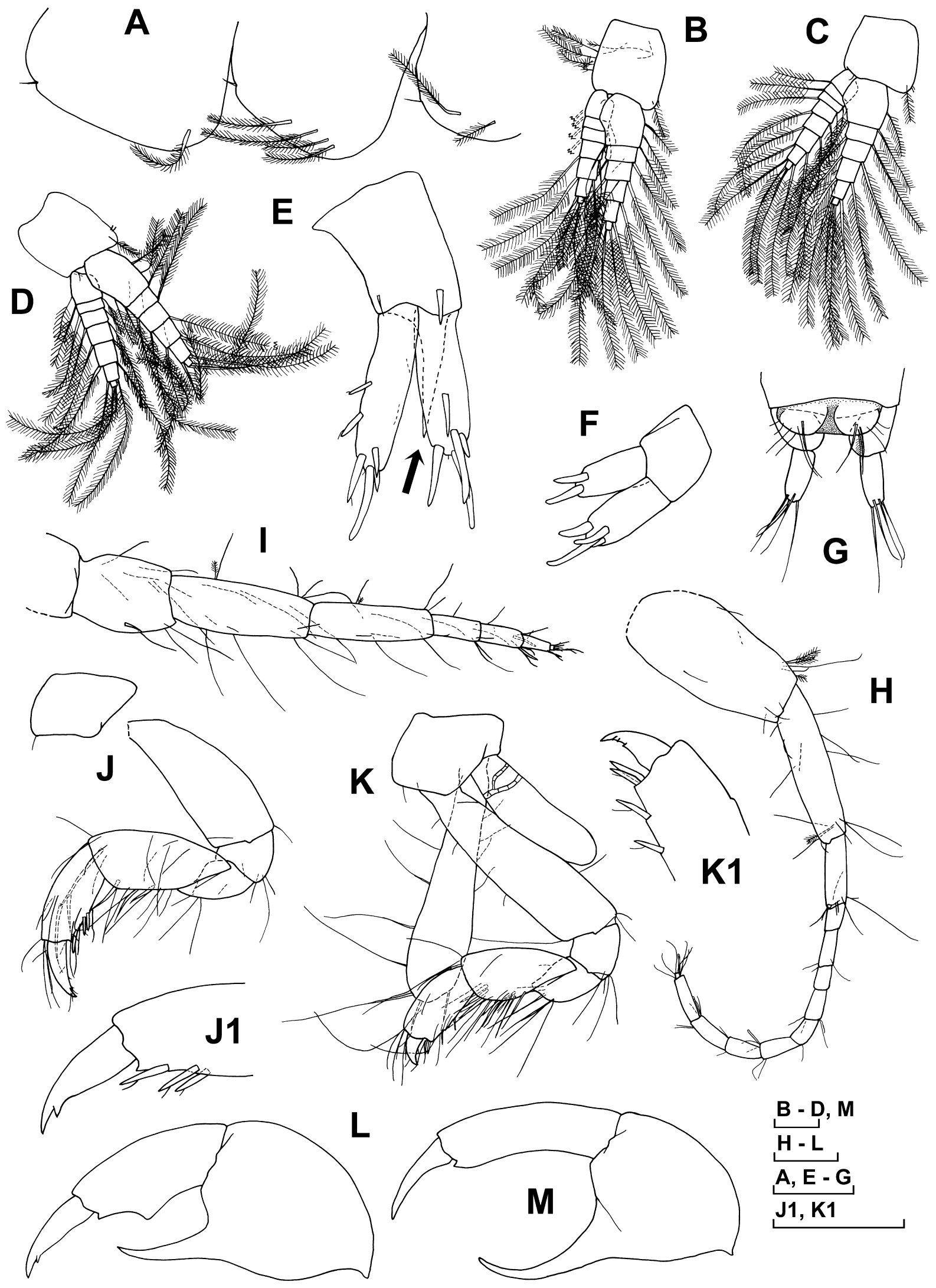

$$
\text { B - D, M }
$$

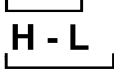

$A, E-G$ J1, K1

Fig. 4. Paragrandidierella urauchiensis sp. nov. A-F, holotype male (OMNH-Ar-9543), $3.1 \mathrm{~mm}$; G, paratype male (OMNH-Ar-9545), $3.0 \mathrm{~mm}$; H-K, paratype female (OMNH-Ar-9548), $2.4 \mathrm{~mm}$; L, paratype male (OMNH-Ar-9546), 2.6 mm; M, paratype male (OMNHAr-9544), $3.2 \mathrm{~mm}$. A, right epimeral plates 1-3, lateral view; B-D, left pleopods 1-3, posterior views; E, F, left uropods 1 and 2, dorsal views (arrow in E indicates inter-ramal process); G, telson and uropods 3, dorsal view; $\mathrm{H}$, left antenna 1, medial view; I, left antenna 2, dorsal view; J, K, left gnathopods 1 and 2, lateral views; J1, K1, distal parts of left gnathopods 1 and 2, lateral views, normal setae omitted; L, M, carpidactyli of gnathopods 1 , lateral views, setae omitted. Scales: $0.1 \mathrm{~mm}$. 


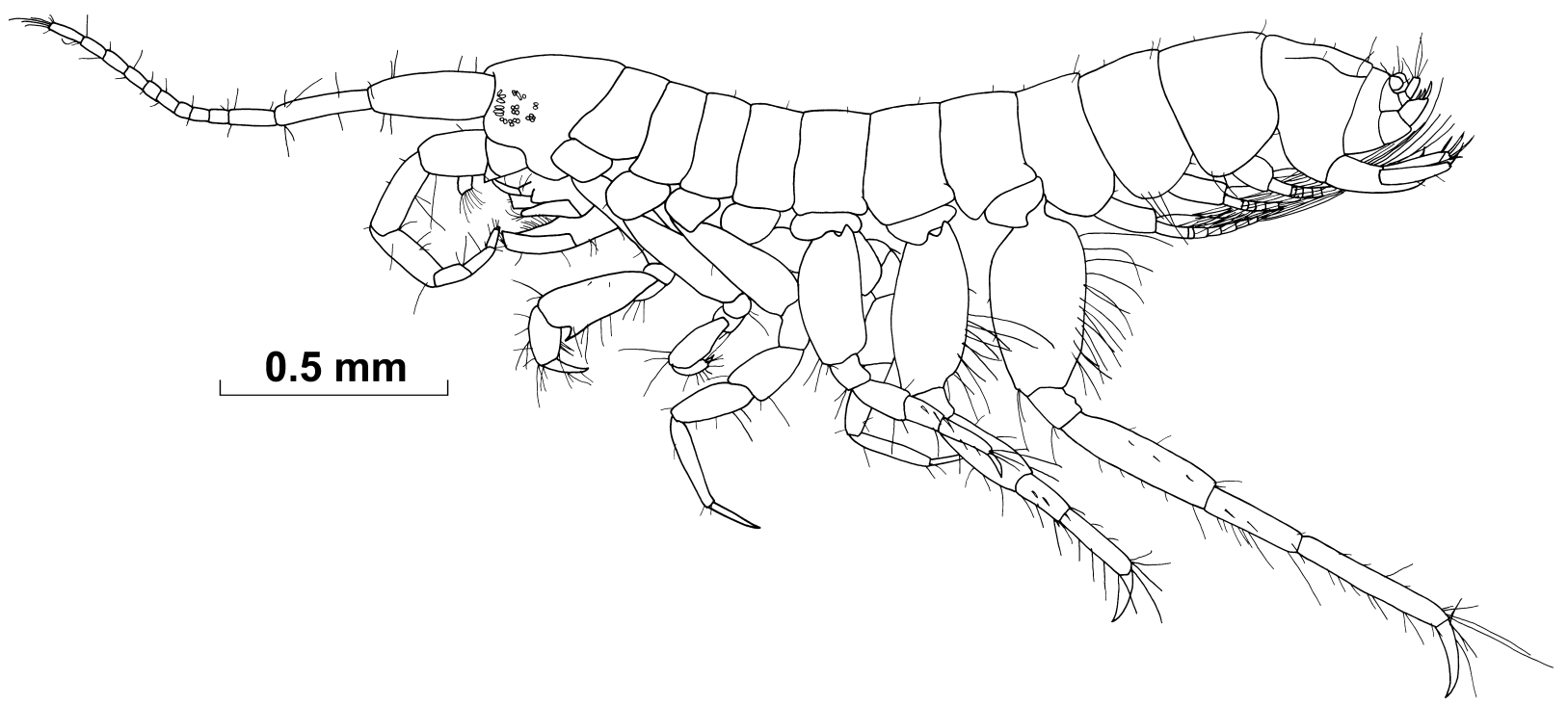

Fig. 5. Paragrandidierella unidentata (Ren, 2006). Male (OMNH-Ar-9552), $2.1 \mathrm{~mm}$. Habitus, left lateral view.

Fig. 4L]: almost same as that of holotype. Large male [paratype, $3.2 \mathrm{~mm}$ (OMNH-Ar-9544), Fig. 4M]: tooth of carpus greatly longer than that of holotype (ca. $95 \%$ as long as carpus proper); propodus long and slender, without expansion.

Etymology. From the type locality.

Remarks. This new species differs from $P$. minima in the absence of an inflated ventrodistal corner of peduncular article 5 in the male antenna 2.

Distribution. Known only from the type locality.

Habitat. Sandy tidal flat, middle to lower intertidal zone (Association of Interdisciplinary Study at the Drainage and Estuarine Area of Urauchi River, Iriomote Island, Southern Japan 2006).

\section{Paragrandidierella unidentata (Ren, 2006)}

(Figs 5-8)

[New Japanese name: Wakaura-himedorosokoebi]

Grandidierella unidentata Ren, 2006: 377, 536, fig. 161.

Material examined. Five males (OMNH-Ar-95499553), 2.4, 2.4, 2.2, 2.1, $1.7 \mathrm{~mm}$, and two females (OMNHAr-9554, 9555), 2.7, $2.3 \mathrm{~mm}$, mouth of Waka River in Wakayama City, Wakayama Prefecture $\left(34^{\circ} 11.0^{\prime} \mathrm{N}\right.$, $135^{\circ} 10.4^{\prime} \mathrm{E}$ ), tidal flat, middle intertidal zone, 13 March 2005, coll. H. Ariyama.

Description of male [based on $2.1 \mathrm{~mm}$ individual (OMNH-Ar-9552)]. Body (Fig. 5) rather stout. Eyes somewhat large ( $30 \%$ as long as head). Posteroventral corners of pereonites 5-7 slightly produced. Urosomite 1 with dorsolateral ridge.

Antenna 1 (Fig. 6A, A1) relatively short, about half as long as body; length ratio of peduncular articles 1-3 $1.0: 0.8: 0.3$, article 1 with dorsal robust seta, articles 1 and 2 each with ventral plumose setae; flagellum with 9 normal and 1 minute articles, articles 4 and 6-9 each with aesthetasc on dorsodistal corner. Antenna 2 (Fig. 6B) short, about 0.3 times as long as body; length ratio of peduncular articles
3-5 1.0:1.5:1.1, article 3 bearing robust seta on dorsal surface, ventrodistal corner of article 5 not inflated; flagellum short, but slightly longer than peduncular article 5, consisting of 3 normal and 1 minute articles, flagellar articles 2 and 3 each with 2 robust setae.

Upper lip (Fig. 6C) with ventral margin slightly concave, bearing many thin setae. Right mandible (Fig. 6D, D1) with length ratio of palp articles $1-3 \quad 1.0: 1.8: 1.9$, articles 2 and 3 with 2 and 10 setae, respectively; incisor with 3 cusps, lacinia mobilis with 2 cusps. Left mandible (Fig. 6E, E1) with length ratio of palp articles 1-3 1.0:1.7:1.9, articles 2 and 3 with 1 and 10 setae, respectively; incisor with 3 cusps, lacinia mobilis with 2 cusps. Lower lip (Fig. 6F) covered with thin setae on apical parts of outer and inner lobes. Maxilla 1 (Fig. 6G, G1, G2) with outer plate bearing 3 robust and 5 normal setae. Maxilla 2 (Fig. $6 \mathrm{H}$ ) with inner margin of inner plate bearing sparse setae. Maxilliped (Fig. 6I, I1) with distal and medial margins of inner plate bearing many plumose setae; outer plate broad, middle and proximal parts not inflated laterally, medial margin with 6 thick, robust setae, tip bearing long, plumose seta.

Gnathopod 1 (Fig. 7A, A1) a little enlarged; carpus wide, posterodistal corner with short tooth ( $c a .15 \%$ as long as carpus proper); propodus straight, posterior margin not expanded, with 2 robust setae; dactylus elongate-triangular, distal part of posterior margin with denticle. Gnathopod 2 (Fig. 7B, B1) slender; posterodistal margin of merus setose; carpus relatively elongate, posterior margin with many thick and normal setae; dactylus with 2 denticles posterolaterally.

Pereopods 3 and 4 (Fig. 7C,D) with coxae roundishrectangular, bases slender, meri dilated distally, carpi about same length as meri, propodi narrow, and dactyli long and dirk-shaped. Pereopod 5 (Fig. 7E) with coxa short, posterior half narrower than anterior; basis rectangular, anterodistal corner with thick seta; merus relatively broad; carpus with 2 lateral and 1 posterodistal robust setae; propodus with 3 lateral and 1 posterodistal robust setae; dactylus short, with plumose seta. Pereopod 6 (Fig. 7F) about 1.4 times as long 

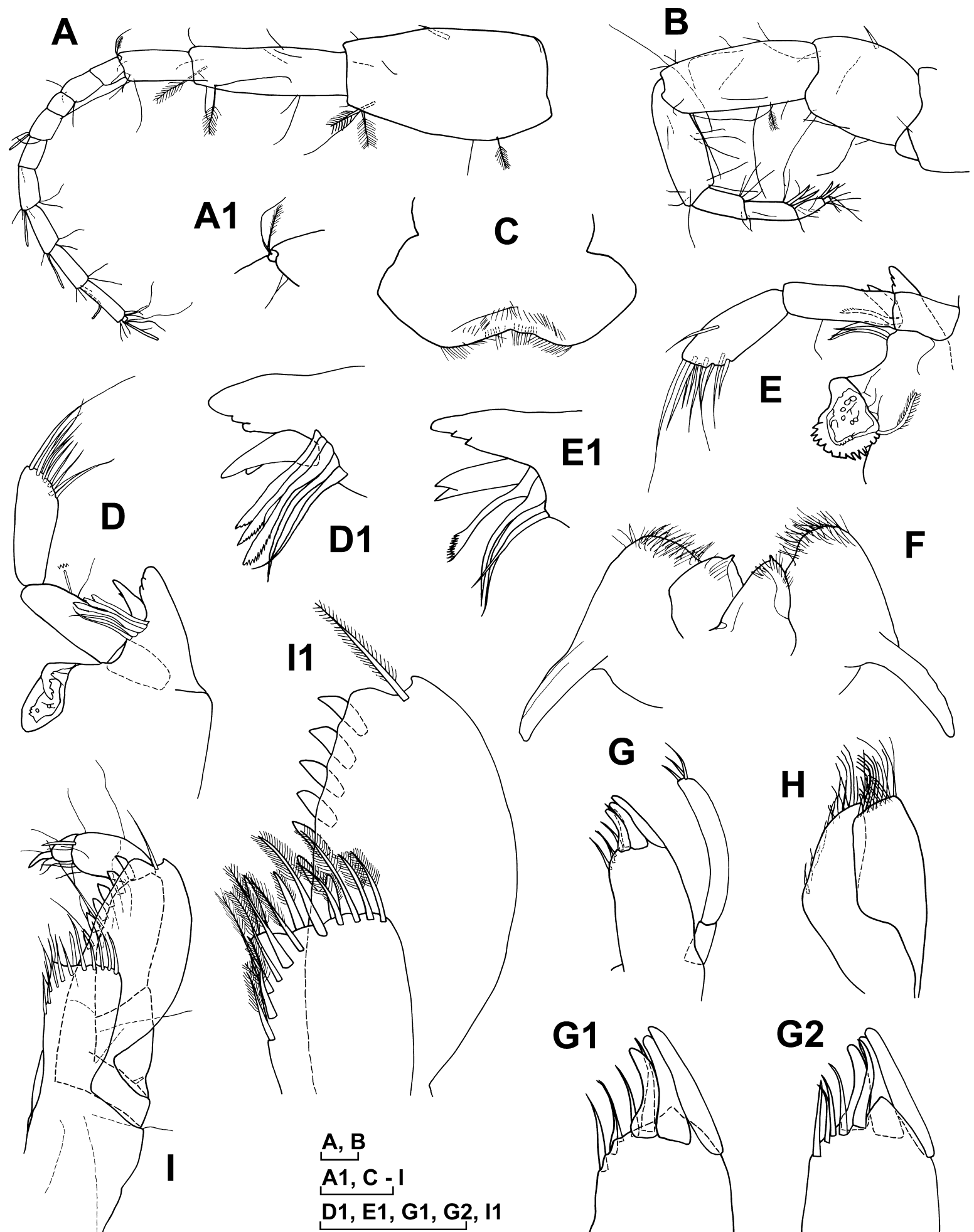

Fig. 6. Paragrandidierella unidentata (Ren, 2006). Male (OMNH-Ar-9552), $2.1 \mathrm{~mm}$. A, left antenna 1, lateral view; A1, accessory flagellum of left antenna 1, lateral view; B, left antenna 2, lateral view; C, upper lip, anterior view; D, right mandible, dorsal view; D1, incisor, lacinia mobilis, and accessory blades of right mandible, dorsal view; E, left mandible, ventral view; E1, incisor, lacinia mobilis, and accessory blades of left mandible, ventral view; F, lower lip, ventral view; G, right maxilla 1, dorsal view; G1, distal part of outer plate of right maxilla 1, dorsal view; G2, distal part of outer plate of left maxilla 1, ventral view; H, right maxilla 2, dorsal view; I, right maxilliped, dorsal view; I1, outer and inner plates of right maxilliped, dorsal view, normal setae omitted. Scales: $0.05 \mathrm{~mm}$.

as pereopod 5; coxa with posterior half narrower than anterior; basis longish ovoidal, anterior margin with 2 short robust setae, distal half of posterior margin with many plumose setae but no robust setae; merus with short lateral ro- bust seta, anterior margin bearing 3 thick setae; carpus with 4 lateral robust setae, anterodistal corner with robust seta and long, thick seta, posterodistal corner with long, thick seta; propodus with 5 thick and 1 robust setae on anterior 


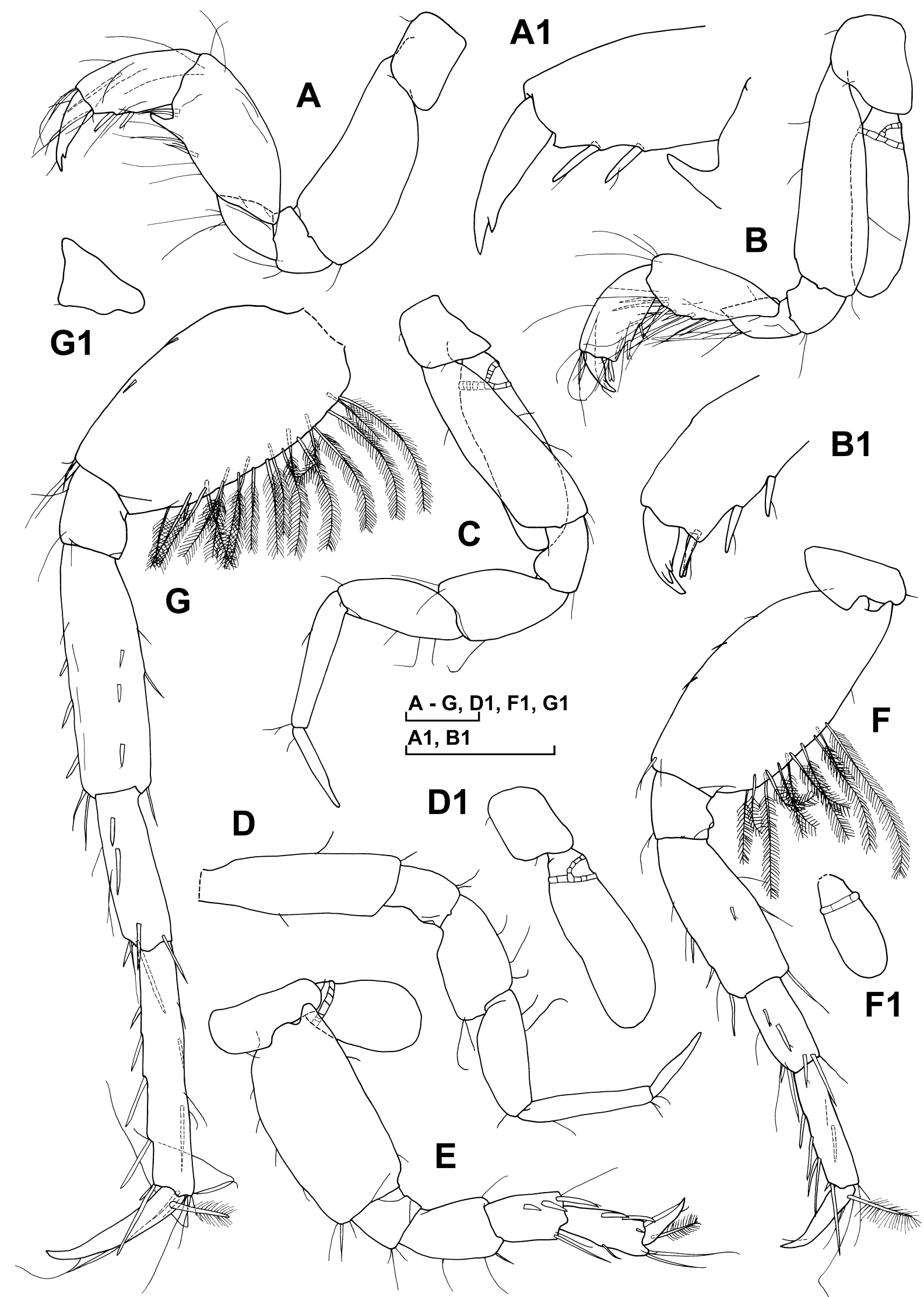

Fig. 7. Paragrandidierella unidentata (Ren, 2006). Male (OMNH-Ar-9552), $2.1 \mathrm{~mm}$. A, left gnathopod 1, lateral view; A1, distal part of left gnathopod 1, lateral view, normal setae omitted; B, left gnathopod 2, lateral view; B1, propodus and dactylus of left gnathopod 2, lateral view, normal setae omitted; C-G, left pereopods 3-7, lateral views; D1, coxa and gill of left pereopod 4, lateral view; F1, coxal gill of left pereopod 6, lateral view; G1, coxa of left pereopod 7, lateral view. Scales: $0.1 \mathrm{~mm}$. 


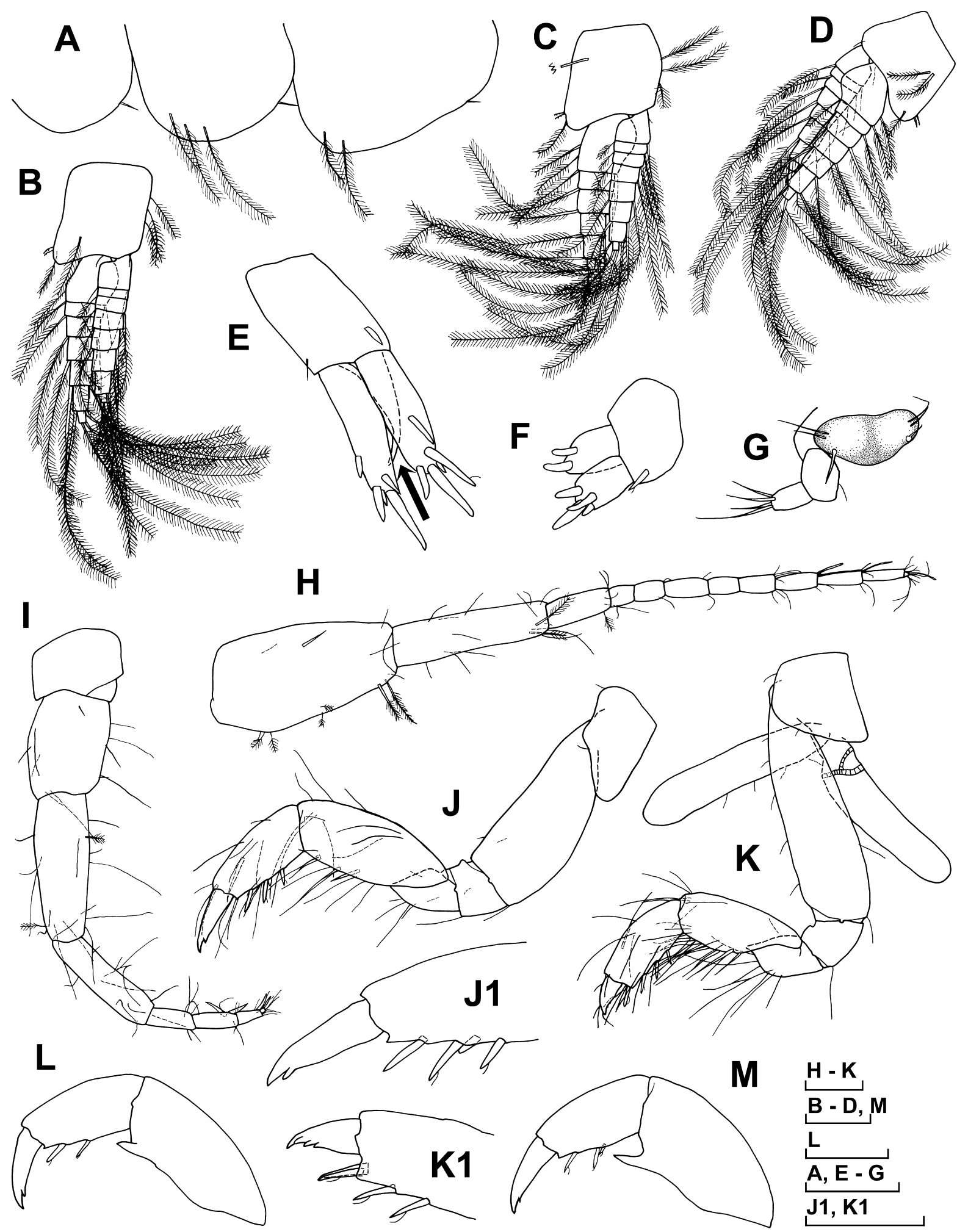

Fig. 8. Paragrandidierella unidentata (Ren, 2006). A-G, male (OMNH-Ar-9552), $2.1 \mathrm{~mm}$; H-K, female (OMNH-Ar-9554), $2.7 \mathrm{~mm}$; L, male (OMNH-Ar-9553), $1.7 \mathrm{~mm}$; M, male (OMNH-Ar-9549), $2.4 \mathrm{~mm}$. A, left epimeral plates 1-3, lateral view; B, C, left pleopods 1 and 2, anterior views; D, left pleopod 3, posterior view; E, F, left uropods 1 and 2, dorsal views (arrow in E indicates inter-ramal process); G, telson and left uropod 3, dorsal view; H, left antenna 1, medial view; I, left antenna 2, lateral view; J, K, left gnathopods 1 and 2, lateral views; J1, K1, distal parts of left gnathopods 1 and 2, lateral views, normal setae omitted; L, M, carpi-dactyli of gnathopods 1, lateral views, normal setae omitted. Scales: $0.1 \mathrm{~mm}$.

margin, medial margin bearing thick seta; dactylus bearing plumose seta. Pereopod 7 (Fig. 7G) about 1.5 times as long as pereopod 6; coxa small, anterior part produced ventrally; basis ovoidal, anterior margin with 2 short robust setae, posterior margin with many plumose and 1 robust setae; merus with 3 lateral and 3 anterior robust setae, anterodistal and 
posterodistal corners bearing thick setae; carpus with 3 lateral and 1 anterodistal robust setae, posterodistal corner and mediodistal edge each bearing long, thick seta; propodus bearing 4 robust setae on anterior margin, anterodistal corner with 1 robust and 1 long, thick setae; dactylus with plumose seta.

Epimeral plates 1-3 (Fig. 8A) each bearing short seta on posteroventral corner; plates 2 and 3 with 3 and 2 long, plumose setae on ventral margin, respectively. Pleopods (Fig. $8 \mathrm{~B}-\mathrm{D})$ with outer rami composed of 8 articles, inner rami composed of 6-7 articles. Uropod 1 (Fig. 8E) stout; dorsal surface of peduncle with 1 robust and 1 normal setae distally; outer ramus slightly longer than inner, outer and inner rami each with 1 dorsal and 4 terminal robust setae. Uropod 2 (Fig. $8 \mathrm{~F}$ ) with peduncle shorter than wide; rami a little shorter than peduncle, outer ramus shorter than inner. Uropod 3 (Fig. 8G) with peduncle a little longer than single ramus, ramus with 4 long setae terminally. Telson (Fig. 8G) with pair of 3 setae.

Description of female [based on $2.7 \mathrm{~mm}$ individual (OMNH-Ar-9554)]. Generally similar to male except for antennae, gnathopods, and oostegites. Antenna 1 (Fig. $8 \mathrm{H}$ ) relatively short, about 0.45 times as long as body; length ratio of peduncular articles 1-3 1.0:0.8:0.3; flagellum with 8 normal and 1 minute articles, articles 5-8 each with aesthetasc. Antenna 2 (Fig. 8I) short, 0.35 times as long as body; length ratio of peduncular articles 3-5 1.0:1.5:1.2; flagellum short, of almost same length as peduncular article 5, consisting of 3 normal and 1 minute articles, flagellar articles 2 and 3 each with 2 robust setae. Gnathopod 1 (Fig. 8J, J1) with coxa trapezoidal; basis broadened distally; merus triangular, posterior margin with a few setae; carpus relatively broad, posterior margin with a few thick and normal setae; propodus slender, distal half of posterior margin with 4 robust setae; dactylus with denticle on distal part of posterior margin. Gnathopod 2 (Fig. 8K, K1) subequal in size to gnathopod 1; similar to that of male, but dactylus with 3 denticles posterolaterally.

Variation in male gnathopod 1 (5 males examined). Small male [1.7 mm (OMNH-Ar-9553), Fig. 8L]: carpus more slender and tooth of carpus smaller than those of OMNH-Ar-9552 (ca. 5\% as long as carpus proper). Large male [2.4 mm (OMNH-Ar-9549), Fig. 8M]: tooth of carpus longer than that of OMNH-Ar-9552 (ca. 15\% as long as carpus proper), posterior margin of propodus with 3 robust setae.

Remarks. The morphological features of this species agree well with those of Grandidierella unidentata Ren, 2006, especially in the shape of the gnathopods and pereopods, but several differences are present [features of Ren's (2006) description in parentheses]: (1) antenna 1 peduncle not slender, relatively short (slender, long), (2) accessory flagellum of antenna 1 vestigial (absent), (3) antenna 2 flagellum with 3 normal and 1 minute articles (4 normal and 1 minute articles), (4) flagellar articles 3 and 4 of antenna 2 each with 2 robust setae (1 robust seta each), (5) palp of maxilla 1 with 3 terminal setae (2 setae), (6) coxa 1 not projecting anteriorly (projecting), and (7) ramus of uropod 3 with 4 terminal setae (2-3 setae). (1), (3), and (6) of these differences may be due to the different body lengths of the specimens: $1.7-2.4 \mathrm{~mm}$ in the present study and $2.8 \mathrm{~mm}$ in Ren (2006). Paragrandidierella unidentata can be distinguished from $P$. minima by the lack of any inflation of male antenna 2, and from $P$. urauchiensis by the smaller tooth of the carpus of male gnathopod 1.

Distribution. Japan: mouth of Waka River, Wakayama Prefecture (present study). China: Qinglan, Hainan Province (Ren 2006). In Japan, this species occurs only in the mouth of the Waka River, where the short-necked clam $R u$ ditapes philippinarum (Adams and Reeve, 1850) has been introduced. Because great quantities of this clam have been imported from China, North Korea, and South Korea to Japan (Ministry of Finance Japan 2013), there is a possibility that Paragrandidierella unidentata is an introduced species like the alien gastropods introduced with various edible bivalves from East Asia (Tamaki et al. 2002; Okoshi 2004).

Habitat. Sandy-mud tidal flat, middle to lower intertidal zone (present study); sand and mud flats with seagrass, littoral (Ren 2006).

\section{Paragrandidierella minima Ariyama, 2002}

(Fig. 9)

[Japanese name: Himedorosokoebi]

Paragrandidierella minima Ariyama, 2002: 155, figs 1-6; Miura, 2008: 109, unnumbered figs; Ariyama, 2012: 177, unnumbered fig; Jung and Yoon, 2013: 259, figs 1-5.

Grandidierella minima: Ren 2006: 368, fig. 156.

Material examined. Holotype: male (OMNH-Ar4922), $2.1 \mathrm{~mm}$, sandy bottom off Kamaguchi, Awaji Island, Hyogo Prefecture $\left(34^{\circ} 29^{\prime} \mathrm{N}, 134^{\circ} 58^{\prime} \mathrm{E}\right), 3 \mathrm{~m}$ deep, $22 \mathrm{Au}-$ gust 1987, coll. M. Tanda and H. Yokoyama. Paratypes: one male (OMNH-Ar-4924), $2.2 \mathrm{~mm}$, and two females (OMNHAr-4923, 4926), 2.1, $1.8 \mathrm{~mm}$, same data as holotype. Five males (OMNH-Ar-9556-9560), 2.8, 2.4, 2.0, 1.8, $1.6 \mathrm{~mm}$, one female (OMNH-Ar-9561), $3.0 \mathrm{~mm}$, and one ovigerous female (OMNH-Ar-9562), $2.9 \mathrm{~mm}$, Funakoshi, Iwagi Island, Ehime Prefecture $\left(34^{\circ} 15.6^{\prime} \mathrm{N}, 133^{\circ} 10.0^{\prime} \mathrm{E}\right)$, sandy bottom, $1 \mathrm{~m}$ deep, 3 August 2002, coll. H. Ariyama.

Description of male. [based on holotype for mouthparts, and another male (OMNH-Ar-9556) for antennae].

Antenna 1 (Fig. 9A, A1) relatively long, about 0.6 times as long as body; length ratio of peduncular articles 1-3 $1.0: 0.8: 0.3$; flagellum with 12 normal and 1 minute articles, articles 8-12 each with aesthetasc on dorsodistal corner. Antenna 2 (Fig. 9B) short, about 0.4 times as long as body; length ratio of peduncular articles 3-5 1.0:1.3:1.1, article 3 bearing robust seta on medial surface, ventrodistal corner of article 5 inflated; flagellum very short, shorter than peduncular article 5, consisting of 4 normal and 1 minute articles, flagellar articles 2-4 with 1,2, and 2 robust setae, respectively.

Mandibles (Fig. 9C, D) with incisors each with 3 cusps, laciniae mobilis each with 2 cusps. Maxilla 1 (Fig. 9E, F) with outer plate bearing 3 robust and 5 normal setae. Maxilliped 


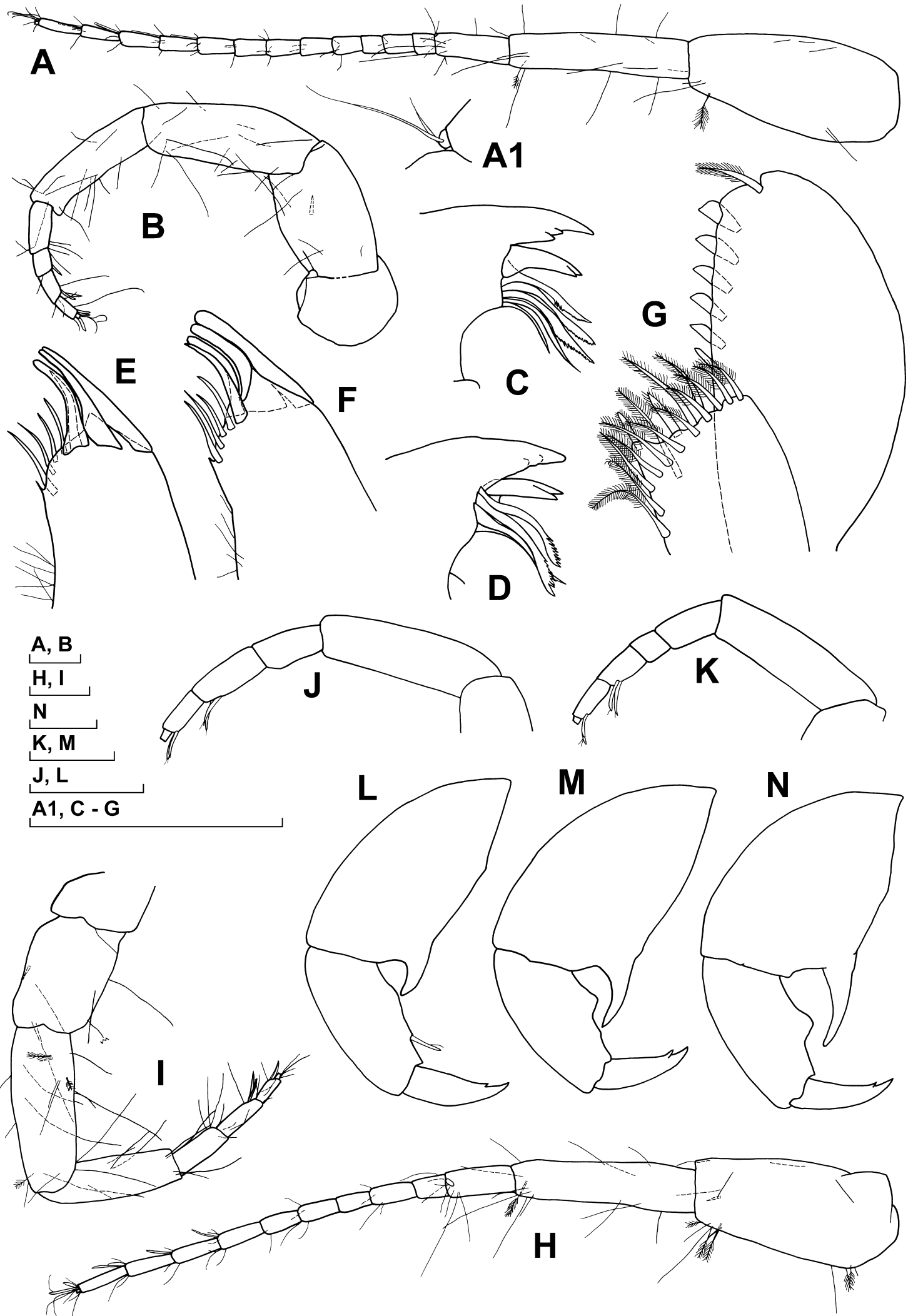

Fig. 9. Paragrandidierella minima Ariyama, 2002. A, B, N, male (OMNH-Ar-9556), $2.8 \mathrm{~mm}$; C-G, holotype male (OMNH-Ar-4922), $2.1 \mathrm{~mm}$; H, I, ovigerous female (OMNH-Ar-9562), $2.9 \mathrm{~mm}$; J, L, male (OMNH-Ar-9560), $1.6 \mathrm{~mm}$; K, M, male (OMNH-Ar-9558), $2.0 \mathrm{~mm}$. A, left antenna 1, lateral view; A1, accessory flagellum of left antenna 1, lateral view; B, left antenna 2, lateral view; C, incisor, lacinia mobilis, and accessory blades of right mandible, ventral view; D, incisor, lacinia mobilis, and accessory blades of left mandible, ventral view; E, distal part of outer plate of right maxilla 1, dorsal view; F, distal part of outer plate of left maxilla 1, ventral view; G, outer and inner plates of right maxilliped, dorsal view, normal setae omitted; $\mathrm{H}$, I, antennae 1 and 2, lateral views; J, K, distal parts of antennae 2, lateral views, normal setae omitted; L-N, carpi-dactyli of gnathopods 1, lateral views, normal setae omitted. Scales: $0.1 \mathrm{~mm}$. 
(Fig. 9G) with distal and medial margins of inner plate bearing many plumose setae, medial margin of outer plate with plumose seta and 6 thick, robust setae.

Description of female [based on ovigerous female (OMNH-Ar-9562)]. Antenna 1 (Fig. 9H) relatively short, about half as long as body; length ratio of peduncular articles 1-3 1.0:0.9:0.3; flagellum with 9 normal and 1 minute articles, articles 6-9 each with aesthetasc on dorsodistal corner. Antenna 2 (Fug. 9I) short, 0.3 times as long as body; length ratio of peduncular articles 3-5 1.0:1.4:1.2; flagellum short, but slightly longer than peduncular article 5 , consisting of 3 normal and 1 minute articles, flagellar articles 2 and 3 each with 2 robust setae.

Variation in male antenna 2 and gnathopod 1 ( 7 males examined). Small male [1.6 mm (OMNH-Ar-9560), Fig. 9J, L]: ventrodistal corner of antenna 2 article 5 not inflated; tooth of gnathopod 1 carpus shorter than that of holotype (ca. 15\% as long as carpus proper), posterior margin of propodus slightly swollen, with robust seta. Medium-sized male [2.0 mm (OMNH-Ar-9558), Fig. 9K, M]: ventrodistal corner of antenna 2 article 5 slightly inflated; tooth of gnathopod 1 carpus of medium length (ca. $25 \%$ as long as carpus proper), posterior margin of propodus swollen, without robust setae. Large male [2.8 mm (OMNH-Ar-9556), Fig. 9N]: tooth of gnathopod 1 carpus longer than that of holotype (ca. $40 \%$ as long as carpus proper); posterior margin of propodus swollen, without robust setae.

Remarks. The morphological features of the specimens collected from Iwagi Island are quite similar to those of the type specimens from Osaka Bay (e.g., inflated ventrodistal corner of peduncular article 5 of male antenna 2), and closely resemble those in the description of Ren (2006) and Jung and Yoon (2013) except for the accessory flagellum.

Distribution. Japan: Tokyo Bay, Seto Inland Sea (Wakayama, Hyogo, Hiroshima, and Ehime Prefectures), and Oita and Miyazaki Prefectures (Ariyama 2012). China: Meixia, Hainan Province (Ren 2006). Korea: Bija-ri, Soanmyeon, Wando-gun, Jeollanam-do (Jung and Yoon 2013).

Habitat. Sandy tidal flats and sandy beaches with high current speed, from middle intertidal zone to upper subtidal zone (Ariyama 2012); among floating seaweed (Ren 2006); among algae in muddy intertidal zone (Jung and Yoon 2013). The habitat reported in China seems dubious, because it is quite different from the Japanese habitat and species of Paragrandidierella and Grandidierella generally inhabit sandy or muddy bottoms.

\section{Key to the Species of the Genus Paragrandidier- ella (for males larger than $2.1 \mathrm{~mm}$ )}

1 Ventrodistal corner of peduncular article 5 of antenna 2 inflated P. minima Ariyama, 2002
- Ventrodistal corner of peduncular article 5 of antenna 2 not inflated.

2 Tooth of gnathopod 1 carpus large (over $50 \%$ as long as carpus proper)............................... P. urauchiensis sp. nov.

- Tooth of gnathopod 1 carpus small (less than $20 \%$ as long as carpus proper)............. P. unidentata (Ren, 2006)

\section{Acknowledgments}

I would like to thank Dr Natsuki Okuda for donating the specimens collected from Iriomote Island, Dr So Ishida of OMNH for lending the type specimens of $P$. minima, and Ms Minako Hanaoka of the Marine Ecological Institute, Inc. for sending literature. I am also grateful to two anonymous reviewers, Dr Mark J. Grygier of the Lake Biwa Museum, and Dr Michitaka Shimomura of the Kitakyushu Museum of Natural History \& Human History for their critical reading of the manuscript.

\section{References}

Ariyama, H. 2002. Paragrandidierella minima, a new genus and species of Aoridae (Crustacea: Amphipoda) from Osaka Bay, central Japan. Species Diversity 7: 155-163.

Ariyama, H. 2012. Himedorosokoebi. P. 177. In: Japanese Association of Benthology (Ed.) Threatened Animals of Japanese Tidal Flats: Red Data Book of Seashore Benthos. Tokai University Press, Hatano. [In Japanese]

Association of Interdisciplinary Study at the Drainage and Estuarine Area of Urauchi River, Iriomote Island, Southern Japan (Matsumoto, C., Okuda, N., Itani, G. and Ariyama, H.). 2006. A multidisciplinary study on biodiversity and traditional natural resource utilization around the estuary of the Urauchi River in Iriomote Island, Okinawa. Grant Research Report of Pro Natura Foundation Japan 15: 11-25. [In Japanese with English abstract]

Jung, T. W. and Yoon, S. M. 2013. First record of the genus Paragrandidierella (Crustacea: Amphipoda: Aoridae) from Korea. Animal Systematics. Evolution and Diversity 29: 259-266.

Ministry of Finance Japan 2013. Trade Statistics of Japan. Available at http://www.customs.go.jp/toukei/srch/index.htm (19 August 2013). [In Japanese]

Miura, T. 2008. Higata no Ikimono-Zukan [Pictorial Guide to Tidal Flat Organisms]. Nanpoushinsha, Kagoshima, 198 pp. [In Japanese]

Okoshi, K. 2004. Alien species introduced with imported clams: the clam-eating moon snail Euspira fortunei and other unintentionally introduced species. Japanese Journal of Benthology 59: 74-82. [In Japanese with English abstract]

Ren, X. 2006. Fauna Sinica, Invertebrata Vol. 41. Crustacea: Amphipoda: Gammaridea (I). Science Press, Beijing, $\mathrm{x}+588$ pp. [In Chinese with English descriptions of new species]

Tamaki, A., Mahori, N., Ishibashi, T. and Fukuda, H. 2002. Invasion of two marine alien gastropods Stenothyra sp. and Nassarius (Zeuxis) sinarus (Caenogastropoda) into the Ariake Inland Sea, Kyûshû, Japan. The Yuriyagai. Journal of the Malacozoological Association of Yamaguchi 8: 63-81. 